\title{
개발도상국가의 SDGs 달성 가속화를 위한 블록체인 기술의 쉬운 이해
}

목 차

I. 서론

II. What: 블록체인이란?

1. 블록체인의 개념

2. 블록체인의 특징

3. 블록체인의 종류

4. 블록체인의 활용 분야

III. Why: 개발에서 블록체인을 주목해야 하는 이유

1. 4차 산업혁명의 기반기술, 블록체인

2. 4차 산업혁명과 개발도상국의 미래

3. 개발도상국에 블록체인이 필요한 이유

4. 개발도상국에 블록체인이 가져올 변화

IV. How: 개발 분야에 블록체인은 어떻게 활용되는가?

1. 금융포용(Financial Inclusion)

2. 사회 · 공공 거버넌스

3. 인도주의적 지원

V. 결론

참고 문헌 


\section{요 약}

블록체인은 4차 산업혁명의 핵심 기반 기술이자 응용 기술로서 모든 영역에 활용될 수 있다. 블록체인과 암호 화폐는 은행조차 없는 개발도상국 시민들에게 금융 접근성을 높여 금융포용을 실현한다. 또한 향후 신분, 재산권을 비롯한 사회공공시스템, 인도주의 원조에 이르기까지 사회 전반에 '잘' 적용된다면 소외 계층들을 기존 사회제도에 편입해 인간의 기본 권리를 보장하고 또 다양한 사회보장 혜택을 제공할 수 있다. 아울러 블록체 인 기술은 원조뿐만 아니라 정치 거버넌스 구조 전반에 투명성과 신뢰성을 확보할 수 있게 한다.

단, 블록체인 기술은 아직 시작 단계에 불과하다. 블록체인 기술은 엄청난 잠재력을 지니고 있지만 기술은 가치중립적 도구이며, 활용하는 사람의 손에 그 결과가 달려 있다. 현재는 기술 자체만으로도 풀어야 할 난제들이 산적해 있다. 이보다 어려운 것은 이를 상용화해 하나의 생태계를 만드는 일이다. 따라서 지속 가능한 개발을 위해 이 기술을 어떻게 활용할 수 있는지에 대해서는 추가 연구와 실험이 반드시 필요하다.

향후 블록체인 기술이 개발도상국의 정치·경제·사회 문화 기반에 올바르게 도입되어 누구에게나 평등한 기회와 정보를 제공하는 플랫폼의 역할을 수행해 줄 것을 기대해 본다. 


\section{I. 서론}

전 세계 인류는 자유무역과 세계화를 앞세워 인류 역사상 가장 번영한 시대에 살고 있다. 그러나 아이러니하게도 전 세계는 그 어느 때보다 불평등하다(탭스코트, 2016). 다가올 4차 산업혁명의 시대는 융합과 연결을 기반으로 사물에 지능을 부여하는 시대이기에 그 어느 때보다 기술 변화의 속도가 폭발적으로 빠를 것이며, 플랫폼을 선점한 자가 시장을 독점할 것이다 (방태웅, 2018). 사물인터넷과 스마트 기술은 만물의 가상화를 가져올 것이며, 빅데이터와 인공 지능을 통해 사회는 그 어느 때보다 빠르게 진화할 것이다. 이 기회를 잡은 기업과 국가는 1 등이 되고, 2 위와의 격차는 2 배 이상 될 것으로 보인다(이경상, 2017). 이를 계기로 저임금 노동력을 기반으로 $1 \cdot 2$ 차 산업 육성의 걸음마를 뗀 개발도상국이나 저개발 국가에는 기회의 요소가 되기도 하지만 위기 요소가 더 많이 존재한다. 뿐만 아니라 개발도상국과 선진국의 기술 격차 및 국가 간 빈곤 격차와 불평등 역시 더 심화될 것이다.

그렇다면 개발도상국에 블록체인 기술이 왜 필요할까? 블록체인 기술의 특징은 “모든 이가 공개된 장부를 가지고 있고, 이 장부의 내용은 위·변조가 불가능하다”는 점이다. 즉, 블록체인 기술은 검증 없이도 정보를 신뢰할 수 있는 사회를 지향하며, 모든 사람이 동등한 정보를 공유하며, 아무도 소외받지 않는 평등하고 민주적이며 서로 신뢰하는 세상을 지향한다. 개발 의 관점에서도 지속가능개발목표(Sustainable Development Goals, 이하 SDGs)1)의 핵심 가치인 '그 누구도 소외되지 않는(leaving no one behind)' 개발을 추구해야 한다는 원칙과도 일맥상통한다.

이에 더해 블록체인 기술은 신뢰를 보증하는 기술이기에 정치·사회·경제에 대한 국민의 신뢰 가 부족한 개발도상국에서 더욱 잘 기능할 가능성이 높다(Niforos, 2018). 특히 블록체인 기술 은 중개 기관의 인프라(예. 은행 등)가 취약하거나 정치·사회·제도적 기반이 부족한 개발도상국 가에 훨씬 더 유용하게 정착될 수 있다. 블록체인 기술의 구현이 공장, 도로, 교통, 통신망과 같은 값비싼 설비투자나 인프라를 요하지 않고, 휴대폰이나 컴퓨터 그리고 인터넷 접근성만 있으면 가능하다는 점도 매력적이다(탭스코트, 2016).

동 보고서 2 장에서는 블록체인 기술의 개념과 특성에 대해 알아보고, 암호 화폐와의 관계

1) 2015년 9월, 국제연합(United Nations, UN) 고위급 정치포럼은 오랜 논의 끝에 새천년개발목표(Millennium Development Goals, 이하 MDGs)에 이어 지속가능개발목표(Sustainable Development Goals, SDGs) 17 개를 선정했다. 이 17 개의 목표들은 종국적으로 세계화의 시스템으로 희생된 인류의 빈곤과 불평등에 대한 반성의 결과물이 다(저자 주). 
및 블록체인의 다양한 적용 영역을 검토해 본다. 3장에서는 4차 산업혁명과 SDGs 시대에 개발도상국 내 블록체인 도입의 필요성을 고찰해 본 후 4장에서는 실제 활용 사례를 통해 향후 개발 분야에서 블록체인 기술을 어떻게 활용할지에 대해 논의해 보고자 한다. 


\section{What: 블록체인이란?}

\section{1. 블록체인의 개념}

블록체인(blockchain)은 사토시 나카모토(Satoshi Nakamoto)의 논문 "Bitcoin: A Peerto-Peer Electronic Cash System”에 비트코인(bitcoin)과 함께 소개된 기술이며, 비트코인 거래의 이중지불2) 문제를 해결하기 위해 등장한 보안 기술이다(GSMA, 2017).

암호 화폐는 전 세계적으로 150 여 종에 달하는데, 그 중에서도 비트코인이 주목받았던 이유 는 바로 블록체인 기술이라는 보안 기술을 활용했기 때문이다. 모든 비트코인 거래는 비트코인 네트워크인 블록체인에 기록된다. 블록(block)이란 이러한 비트코인 거래를 10 분 단위로 기록 한 디지털 묶음이라 할 수 있으며, 블록체인(blockchain)이란 동 디지털 기록물을 하나로 묶은 장부로 이해할 수 있다(이민화, 2017; 김성준, 2017; Nakamoto, 2008).

이 거래 내역이 네트워크 참여자게 모두 공개되고, 분산·관리되기에 공공거래장부 또는 분산 원장이라고도 불린다. 누구나 블록체인 네트워크상에서 일어난 모든 거래를 열람하고 진위를 증명하는 데 참여할 수 있다(금융보안원 보안연구부, 2017; 이제영, 2017). 비트코인 거래 내역 은 공개키와 개인키가 함께 움직인다. 거래 내역은 블록체인에 아직 연결되지 않은 채 공개키와 함께 SNS처럼 모든 사람에게 공유된다. 기본적으로 철저한 ‘익명'이며 또 ‘암호화’되어 있다.3) 네트워크의 참여 노드)들은 이 암호화된 무작위 값을 수학적으로 검증해 해당 거래의 진위를 증명한다. 가장 먼저 증명해 낸 노드는 비트코인을 보상으로 받게 되고 과반수의 동의를 얻은 후 블록체인으로 연결된다.

2) 디지털 화폐이기 때문에 인터넷 환경에서 문서 파일처럼 쉽게 복사되고 또 위· 변조되어 중복으로 제시해도 양쪽에서 문제없이 사용할 수 있는 것을 이중 지불이라고 한다.

3) $\mathrm{A}$ 가 B에게 50 비트코인을 보낸 기록은 공유되지만, $\mathrm{A}$ 와 $\mathrm{B}$ 가 누구인지는 알 수 없고 또 거래 정보는 개인키로 서명을 통해 암호화된 무작위 값으로 되어 있다.

4) Node(노드)란 간단히 말해, 비트코인 채굴에 참여하는 참여 컴퓨터들을 의미한다. 데이터 간 기지를 뜻하며, 데이터의 송수신, 전송, 저장 등의 기능을 한다. 비트코인의 안정성을 유지하기 때문에 비트코인 네트워크에서 노드는 매우 중요하다. 
〈그림 1〉 블록체인의 원리 이해

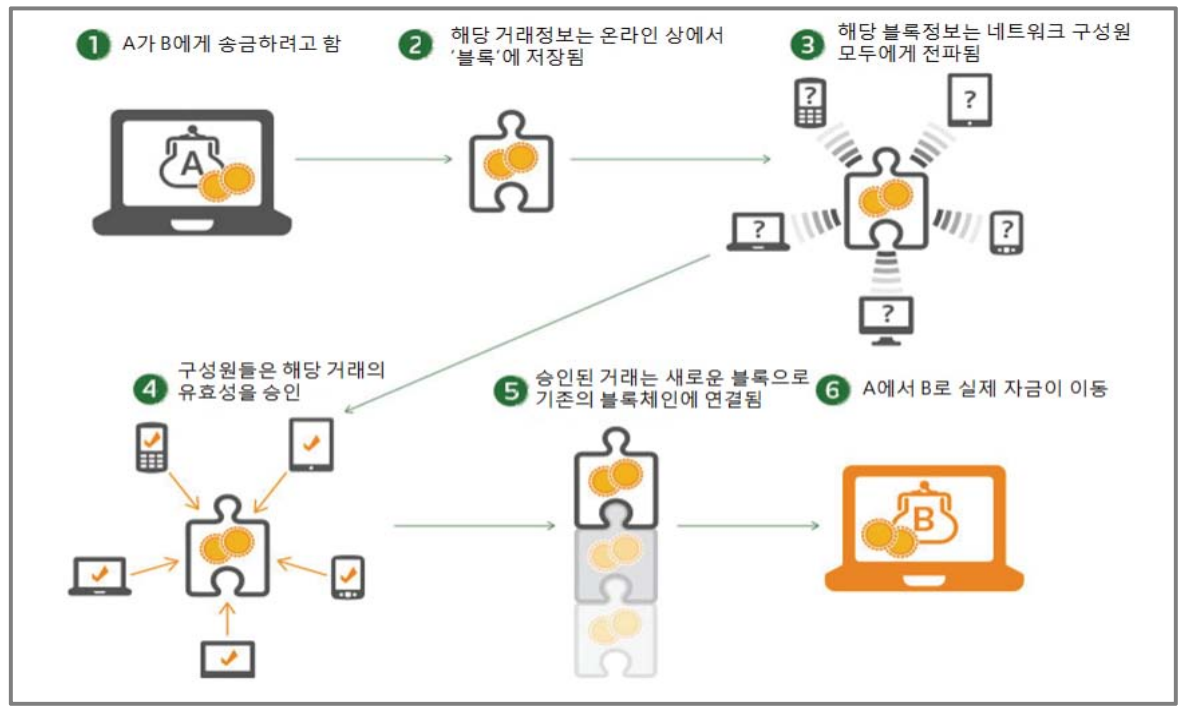

출처: 이제영 (2017)

\section{2. 블록체인의 특징}

\section{1) 중개인이 필요 없다 - 탈중앙화 분산성}

수세기 동안 은행은 원장을 통해 계좌 거래 데이터베이스를 유지·관리했으며, 정부는 토지소 유권이나 모든 공공 기록을 중앙집중형으로 보관·유지해 왔다(Philip Boucher et al., 2017). 디지털화 덕분에 이러한 전통 원장은 더 빨라지긴 했지만 여전히 느리고 비효율적이며, 이를 운영하는 중개 기관은 독점적 권리를 행사한다(Philip Boucher et al., 2017).

블록체인 네트워크는 거래 기록 기능은 유지한 채 탈중앙화된 시스템을 구축하고 있다. 신뢰 를 증명하는 과정을 대신 보증해 주는 중개인 없이 빠르고 정확하게, 참여자들의 컴퓨터가 자동으로 증명하는 시스템이 바로 블록체인이다(탭스코트, 2016).

참여자들이 진위 검증(채굴 혹은 마이닝)5) 과정을 거치고 나면 과반수 이상 동의로 블록체인 에 기재되고, 이 블록체인은 참여자에게 모두 분산되어 안전하게 보관된다. 따라서 신뢰를 보증

5) 마이닝(Mining)에 대한 보상이자 참여 동기로 제공되는 것이 바로 비트코인이다(동 보고서는 개발 영역의 블록체인 활용을 쉽게 이해하기 위한 보고서이기에 비트코인 및 블록체인에 대한 공학적 원리 및 기술적인 측면에 대해서는 상세히 다루지 않는다). 
해 주는 중앙집권적 중개인 없이도 개인 대 개인(Peer to Peer, 이하 P2P) 간의 상호작용이 가능하다.

〈그림 2〉 기존 거래와 블록체인 거래와의 차이점

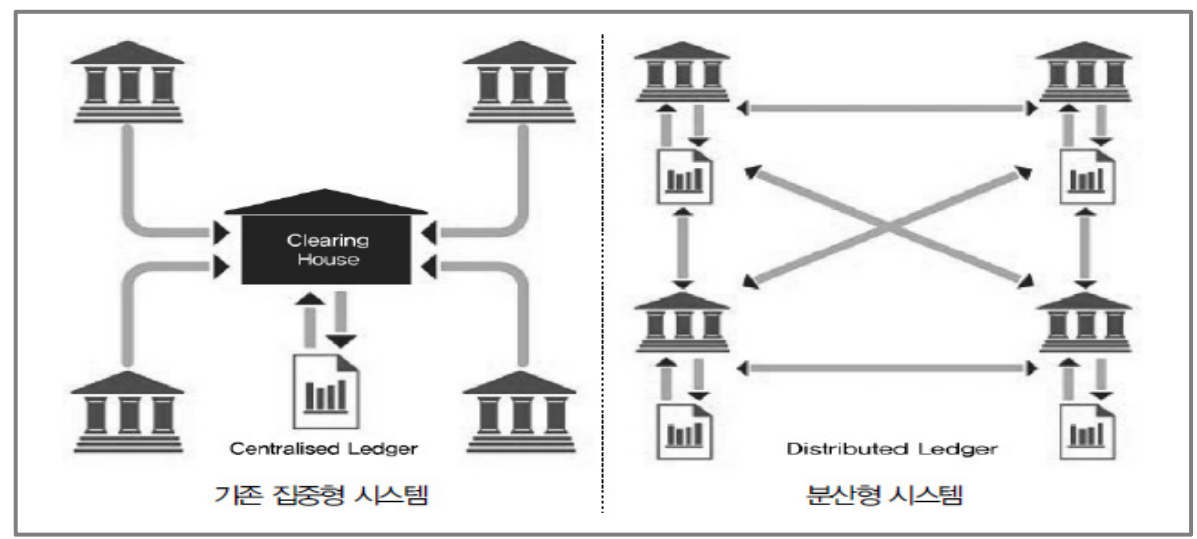

출처: 김성준 $(2017)$

\section{2) 보안성·투명성· 불가역성}

여기까지 읽으면, ‘모든 사람에게 공유된다면 보안은?’이라는 의문이 들 것이다. 많은 전문가 가 블록체인 기술 자체는 해킹이 절대 불가능하다고 자신 있게 말한다.6) 그 기저에는 해쉬 (hash)라는 불가역 암호함수가 있다. 실제 거래 내용과 거래 당사자 정보는 해쉬 알고리즘을 통해 특정한 길이의 무작위 값으로 치환된다(이민화, 2018).

해쉬 알고리즘(함수)은 투입 값을 결코 유추할 수 없는 무작위 암호 기술을 통한 결과 값으로, 투입 값의 아주 작은 부분이라도 달라질 경우에는 그 결과값의 모든 정보가 바뀌게 된다. 비트코 인 거래를 확증하기 위해 참여자(컴퓨터)들은 입력 값의 반복 대입을 통해 특정 조건을 충족시 키는 해시(암호 값)를 찾아낼 뿐이며, 찾을 확률은 오로지 컴퓨팅 파워에 비례한다.

블록체인은 타임스탬프 기능이 있다. 데이터가 어떤 시각에 확실하게 있었던 것을 증명하는 기능이다. 이전 블록과 현재 블록이 연결 구조를 들여다보면 현재 블록에 직전 블록의 값이 기재되어 있다(<그림 $3>$ 참조).

6) 우리가 접하는 비트코인 해킹 뉴스나 기사는 거래소 해킹을 의미한다. 거래소는 암호 화폐를 중앙집중화 형태로 보관한다. 즉, 기존 은행과 동일한 방식이므로, 종종 해커들의 타깃이 된다. 
따라서 누군가 현재 90 번째 블록까지 연결된 블록체인에서 74 번 블록의 거래 내역을 조작하 고자 한다면, 74 번부터 90 번까지 연결된 모든 블록을 다음 블록 생성 전 10 분 동안 연결해야 한다(임명환, 2016). 이는 현실적으로 불가능하다. 블록체인 기술은 바로 이러한 특성, 데이터의 위·변조성이 차단되고 추가 삭제 및 변경이 불가능한(비가역적) 특성으로 말미암아 보안과 신뢰가 필요한 모든 산업 분야에서 각광받고 있다.

〈그림 3〉 블록체인 내 블록 구조

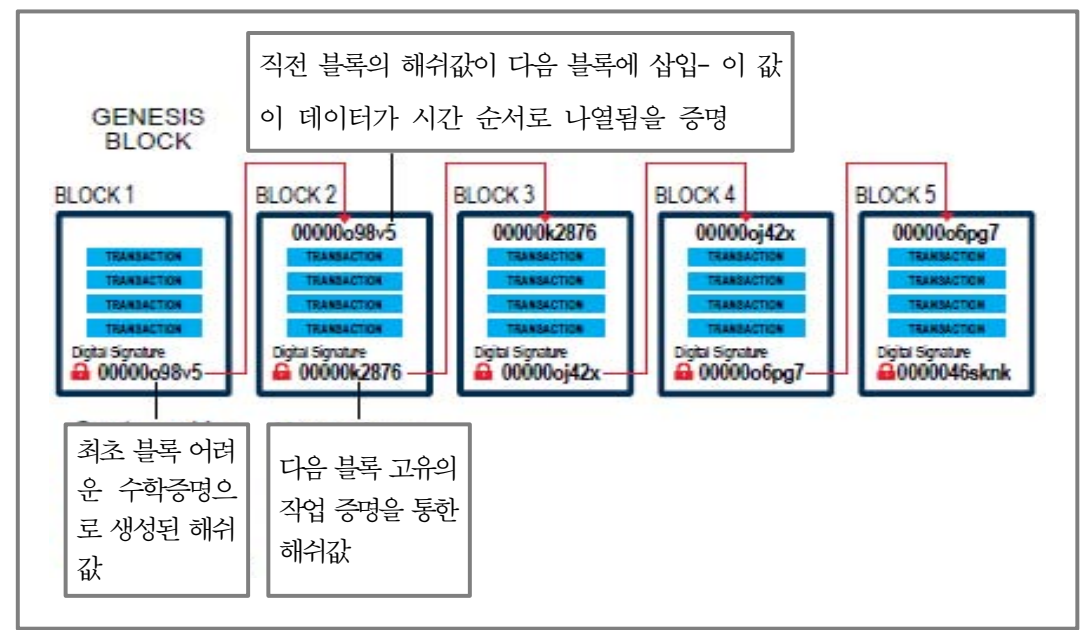

출처: World Bank (2017)

\section{3. 블록체인의 종류}

블록체인은 참여 및 접근 방식에 따라 <표 $1>$ 과 같이 나뉜다. 퍼블릭 블록체인(public block chain)은 모든 이가 참여하고 접근할 수 있는 네트워크로서 비트코인이나 암호 화폐에 주로 활용되는 네트워크다. 반면, 프라이빗 블록체인(private block chain)은 공공성을 띠지 않은 블록체인으로서 개인이나 기관에 모든 권한이 있는 형태다. 또한 컨소시엄 블록체인(consotium blockchain)은 상호 합의된 소수의 주체들이 컨소시엄 형태를 이루어 각 기관의 동의에 의해 거래가 생성되는 구조다(이민화, 2018; 이대기, 2017).

지금까지 비트코인의 사회적 파장과 시장의 혼란은 전 세계 모든 거래 참여자에게 공개된 퍼블릭 블록체인 네트워크가 안정적인 생태계와 위험 관리 장치 없이 선보이면서 일어난 역작용 이라고 말할 수 있다. 프라이빗이나 컨소시엄은 이러한 문제에서 자유롭다(박성준, 2018). 향후 개발도상국의 난제를 해결하기 위해 주로 논의하는 블록체인 분야의 응용기술 역시 송금 분야를 제외하고는 주로 프라이빗 블록체인 혹은 컨소시엄 블록체인에 기반을 두고 있다. 
〈표 1〉 블록체인의 종류

\begin{tabular}{|c|c|c|}
\hline 유형 구분 & 개념 및 특징 & 주요 활용 사례 \\
\hline $\begin{array}{l}\text { 퍼블릭 블록체인 } \\
\text { (public blockchain) }\end{array}$ & $\begin{array}{l}\text { - 모든 사람에게 공개 및 운용 } \\
\text { - 네트워크 확장이 어렵고 거래 속도가 느림 } \\
\text { - 최초의 블록체인 활용 사례 }\end{array}$ & $\begin{array}{l}\text { 암호 화폐, 민간 공증. e.g.비트 } \\
\text { 코인, 라이트코인, 이더리움 등 }\end{array}$ \\
\hline $\begin{array}{l}\text { 프라이빗 블록체인 } \\
\text { (private blockchain) }\end{array}$ & $\begin{array}{l}\text { - 개인형 블록체인 } \\
\text { - 하나의 주체가 내부 전산망을 블록체인으로 관리함 } \\
\text { - 한 중앙기관이 모든 권한 보유 }\end{array}$ & $\begin{array}{l}\text { 민간 바우처, 국가공증. e.g. 나 } \\
\text { 스닥, Overstock 등 }\end{array}$ \\
\hline $\begin{array}{l}\text { 컨소시엄 블록체인 } \\
\text { (consortium } \\
\text { blockchain) }\end{array}$ & $\begin{array}{l}\text { - 半 중앙형 블록체인 } \\
\text { - 미리 선정된 소수(N) 주체들만 참여 } \\
\text { - 주체 간 합의를 통해 참여 가능 } \\
\text { - 네트워크 확장이 용이하고 거래 속도가 빠름 }\end{array}$ & $\begin{array}{l}\text { 은행 프로젝트. e.g. R3, CEV, } \\
\text { HSBC, Citi, Goldman Sachs } \\
\text { 등 }\end{array}$ \\
\hline
\end{tabular}

출처: 금융보안원 보완연구부 (2017); 이민화 (2018); 이대기 (2017)

\section{제 I 장 \\ 제II 장 \\ 섹 \\ 터 \\ 포 \\ 커 \\ 스}

제피장

\section{4. 블록체인의 활용 분야}

블록체인 기술은 보안성 - 투명성 - 신속성 등이 필요한 모든 분야에 도입이 모색되고 있으며, 블록체인 응용기술은 지속적으로 증가하고 있다.

응용 플랫폼의 활용은 암호 화폐, 공공-보안, 산업, 거래 결제 등 다양한 분야로 뻗어 나가는 추세다. 시작은 화폐 및 송금 분야에서 출발했지만 현재는 스마트 계약을 필두로 유통, 전자투표 (거버넌스), 신분 확인 등 비금융 산업 및 공공 분야로도 확산되고 있는 추세다(임명환, 2018).

〈그림 4〉 블록체인 기술 산업응용 분야

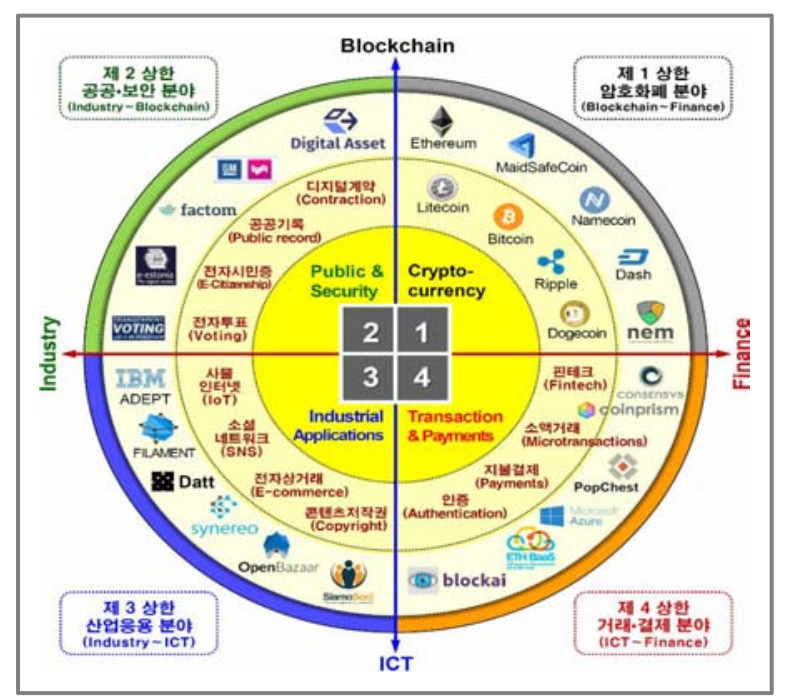

출처: 임명환 (2016) 


\section{Why : 개발에서 블록체인을 주목해야 하는 이유}

\section{4차 산업혁명의 기반기술, 블록체인}

다보스포럼의 주최자인 세계경제포럼(World Economic Forum)은 블록체인 기술이 4차 산업혁명을 견인하는 7대 기술 중 하나라고 밝혔다(이제영, 2017). 특히 블록체인이 주목받는 이유는 위·변조 방지와 데이터의 신뢰성을 보장하는 기술 특성을 지녀 나머지 기술의 기반이 되기 때문이다(이영환, 2016). 4차 산업혁명 시대에서는 사람과 사람(Peer to Peer, 이하 P2P), 사람과 사물(Person to Machine, P2M), 사물과 사물(Machine to Machine, M2M)이 온 - 오프라인을 넘나들며 긴밀하게 연결될 것이다(김성준, 2017). 이러한 초연결 사회의 도래는 제3자의 개입 없이 네트워크 구성원 간 협업이 가능하고, 투명성과 안정성을 확보할 수 있는 새로운 형태의 플랫폼 개발 및 확산을 필요로 한다. 이에 부합하는 기술이 바로 블록체인이다.

〈그림 5〉 다보스포럼 선정 7대 기술의 상호 의존성

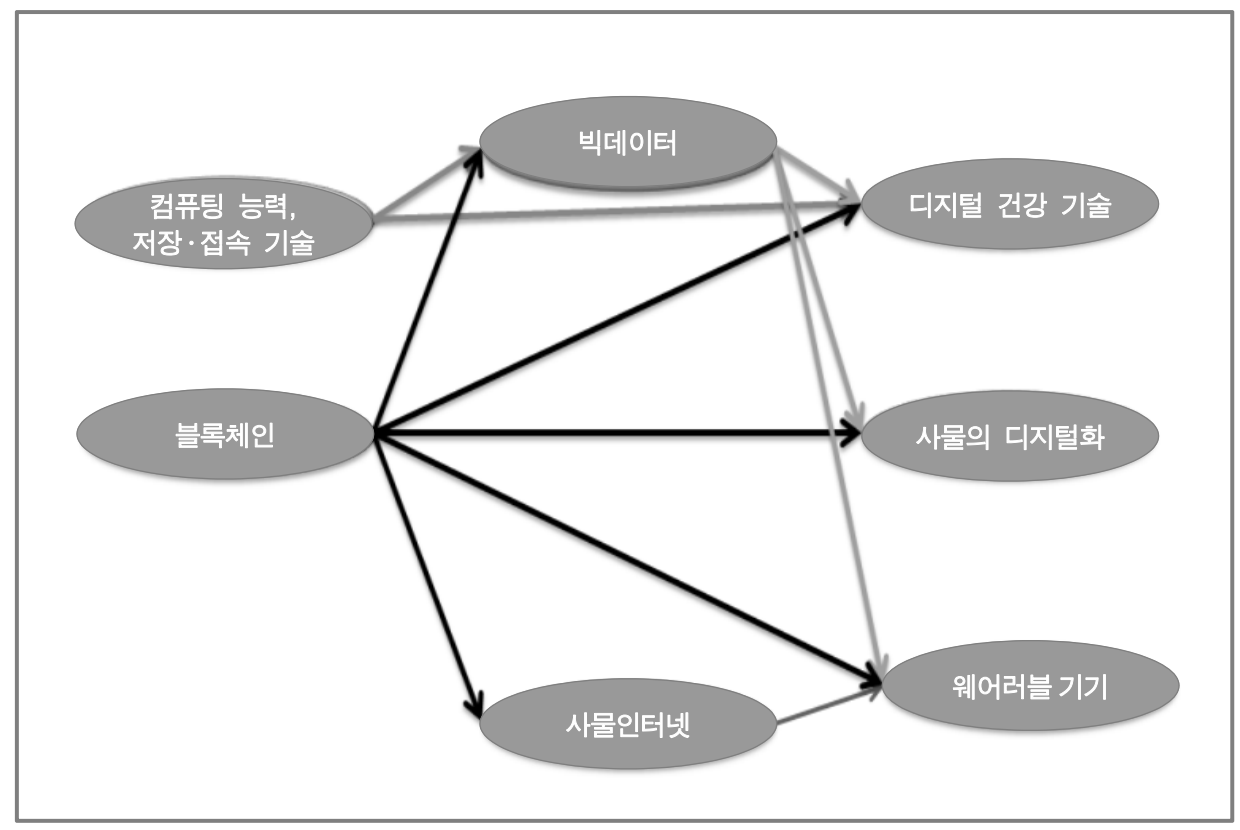

출처: 이영환 (2016) 


\section{4차 산업혁명과 개발도상국의 미래}

1) 부정적 견해

제 I 장

산업혁명의 가장 큰 특징은 승자 독식의 체제라는 점이다(슈왑, 2016). 1차 산업혁명은 영국 을 승자로 만들었고, $2 \cdot 3$ 차 산업혁명은 미국을 세계 최강의 패권 국가로 변모시켰다. 4 차 산업혁명 역시 기본기가 부족한 개발도상국에게는 불리한 싸움이 될 것이라는 견해가 대다수다.

개발도상국의 스필오버 효과(spillover effect)가 단절된다는 것은 개발도상국의 기술 축적 을 통한 선진국과의 진입 장벽 사다리가 사라진다는 의미이기도 하다(윤유리, 2017). 사이버물 리시스템(Cyber-Physical System, CPS) 기반의 스마트 공장은 개발도상국이 경쟁력을 지 니던 풍부한 저숙련 단순노동인구에 대한 대량 실업을 예고한다(윤유리, 2017). 근본적으로 블록체인은 탈중개인 서비스를 표방하므로 많은 일자리가 사라지게 될 것은 분명하다.

세계 최고의 경영연구소 중 하나인 맥킨지 글로벌연구소(McKinsey Global Institute) 보고 서(2016)에 따르면 빅데이터, 자동화, 사물인터넷, 자율주행차 등 4차 산업혁명의 모든 영역에 서 선진국들의 독점 현상이 지속될 것이며, 정보통신 및 제조업 인프라가 부족한 신흥국들은 상당히 고전할 것으로 예측했다.

\section{2) 긍정적 견해}

한편, 4 차 산업혁명으로 인한 초연결 사회의 진입으로, 시장 진출의 진입 장벽이 낮아져 개발도상국에도 기업 창출 및 혁신의 기회가 주어진다는 견해도 있다(윤유리, 2017 ; 이제영, 2017). 개발도상국 기업이나 스타트업도 창의적이고 혁신적인 아이템으로 오픈플랫폼을 활용 한 참여가 가능해진다면 시장 진입이 수월할 것이다(윤유리, 2017).

또한 자영업이나 소규모 자본 창업가들이 개발도상국 경제의 주류이기에(케이시·비냐, 2017), 소상공인의 거래비용 절감과 비용 조달, 자산과 재산권 보장을 해준다면 라인업을 확장 하고 또 거래처를 확장하는 등 다른 영역에 혁신의 촉매제가 될 수도 있다(탭스코트, 2016). 4 차 산업혁명의 기술이 합법적으로 올바르게 운영된다면 현재 자본주의 경제의 난점을 해결할 독보적인 기술 해결책이 될 수도 있다(탭스코트, 2016). 국가 간 불평등을 해결할 수 있는 실마리가 되어 줄 가능성도 존재한다. 개발도상국의 송금 비용을 낮추며, 쉬운 계좌 개설, 투자 제약을 타파, 창업을 독려해 자본주의 재분배를 넘어서 분산 자본주의를 꾀할지도 모를 일이다 (탭스코트, 2016). 


\section{3. 개발도상국에 블록체인이 필요한 이유}

\section{1) 불안정한 화폐 경제와 인플레이션 문제}

선진국의 경우, 이미 신뢰 가능한 정부나 효율적인 중앙기관이 존재하기에 기존 시스템을 버리고 탈중앙화 시스템과 새로운 화폐를 도입할 필요성이 거의 없다(The 4th Wave, 2018). 반면, 개발도상국의 경우에는 화폐 인플레이션 문제와 신뢰할 수 있는 중앙기관 및 인프라가 취약하다. 따라서 역설적으로 설명하자면, 실제로 암호 화폐와 블록체인 기술이 훨씬 효과적으 로 작용할 것이다(The 4th Wave, 2018; Niforos, 2018). 현재 비트코인이 가장 활성화된 국가는 남미의 아르헨티나다. 이 국가는 자국 화폐가 불안정하고 인플레이션 문제를 겪기 때문 에 헤징 수단으로 비트코인을 더욱더 활용하고 있다.

\section{2) 중앙기관 및 제도의 낮은 신뢰성과 투명성}

개발도상국들은 현재 전례 없는 기술 발전에도 불구하고 공통적으로 다양하고 복잡한 사회개 발과제(e.g 빈곤, 불평등, 인플레이션)와 취약한 기본 국가제도를 지니고 있다. 고질적이고 구조 적인 시스템 문제는 어떠한 기술도 무용지물로 만들어 버린다. 이는 공적원조뿐만 아니라 민간 투자도 어렵게 한다. 각종 원조 자금의 전달 수단인 블록체인 기재나 부동산 등록이 자동으로 이루어지는 스마트 계약의 도입은 인간의 조작이나 개입을 최소화한다. 따라서 시스템으로 민주적 평등의 가치를 보장하는 블록체인 기술의 도입이 투명성과 신뢰성이 필요한 개발도상국 에 어쩌면 더 절실할지도 모른다.

\section{3) 높은 자영업자 비율}

개발도상국에 블록체인이 더 필요한 이유는, 개발도상국에는 자영업 또는 어·농업 등 1 차 산업에 종사하는 사람들의 비율이 상당히 높다는 점이다(탭스코트, 2016). 소기업 소유주나 자영업자들이 신흥 경제의 핵심 동력인데, 소액 거래나 계좌 없이도 신용보증이나 대출이 가능 하다면 블록체인 기술은 개발도상국 국가의 경제 활성화에 기여할 것이다.

\section{4) 높은 인터넷 및 휴대폰 보급률}

개발도상국은 금융업에 기반을 두고 있으나 제조업 및 기타 첨단산업에 필요한 고비용의 산업 인프라가 취약하다. 그러나 블록체인 기술은 인터넷과 기본 기능의 휴대전화만 있다면 
손쉽게 구현할 수 있다. 현재 아프리카 성인의 20\%만 계좌를 보유한 것에 비해, 2017년 기준으 로 전체 인구의 $2 / 3$ 인 약 50 억 명이 휴대전화를 사용하고 있다. 아마도 2020 년까지 전 세계인의 $75 \%$ 가 휴대전화를 사용할 것으로 예측된다(GSMA, 2017).

현재 남미에서 가장 빈곤한 볼리비아의 시골에도 인터넷 카페가 있으며, 웬만한 선진국보다 그 속도가 빠르다(케이시·비냐, 2017). 이는 많은 개발도상국가가 유선전화 인프라를 거치지 않고 첨단 광섬유 케이블을 도입해 모바일 시대로 뛰어올랐기 때문이다.

케냐에서는 엠페사(M-Pesa)7)라는 모바일 기반의 결제송금서비스가 전 국민적인 호응을 얻 고 있다. 2007년에 서비스를 시작한 이후 2015년 기준 국내총생산(Gross Domestic Product, 이하 GDP)의 $47 \%(207$ 억 달러)가 모바일로 결제되었고, 연간 이용 건수는 13 억 8천만 건에 이른다(전희수, 2017). 이는 신기술을 통해 개발도상국의 고비용 은행 시스템을 거치지 않고서 도 새로운 경제성장 패러다임을 만들어 낼 수 있다는 것을 증명해 낸 고무적인 사례다. 블록체인 기술 역시 특정 단계를 뛰어넘어 도약할 수 있는(leapfrog) 기술로서 주목받고 있다.

\section{5) 암호 화폐 생태계의 활성화}

개발도상국은 선진국보다 암호 화폐 생태계가 더 탄탄히 구축되고 있다. 동남아시아 중에서 도 인도네시아와 베트남은 암호 화폐 거래 이용자 수가 주식 거래 이용자 수를 추월할 만큼 열기가 뜨겁다(한국경제 매거진, 2018). 아울러 아프리카의 나이지리아, 가나, 케냐, 남아공 등 4개국은 이미 암호 화폐 생태계가 구축되어 있다(Danida et al., 2017).

세계은행(World bank)은 아프리카 내에 173 개의 첨단 허브와 창업육성센터를 확인했고, 가장 널리 알려진 케냐의 iHub에서는 150 개가 넘는 스타트업이 세워지고 있다(Savoy and Rice, 2017). 실리콘 사바나라고 불리는 아프리카의 IT실리콘밸리에서는 블록체인 스타트업 기업들이 속속 등장하고 있다. 특히 고무적인 점은, 위 사례를 통해 알 수 있듯이 암호 화폐를 단순히 투기 수단이 아닌 블록체인 기술의 일부로 받아들이며 활용도가 늘어나고 있다는 점이 다. 4차 산업혁명 시대를 맞이해 개발도상국이 더 빠른 블록체인 생태계를 구축하고 있을지 모를 일이다.

7) $\mathrm{M}-\mathrm{PESA}$ 는 영국국제개발부(Department for International Development, DFID)와 다국적 통신회사인 보다폰 (Vodafone)이 매칭펀드로 제안한 사업이다. 케냐의 사파리콤 통신회사가 2007년에 출시해, 핸드폰을 사용해 모바일 머니로 상대에게 안전하고 빠르게 송금하는 서비스다. 휴대폰 번호가 곧 하나의 계좌로 기능하며, 이동통신사가 은행 역할을 해 곳곳에 위치한 모바일 머니 대리점에서 ATM처럼 모바일 머니 계좌로 현금을 입금하고 또 인출할 수 있다(전희수, $\mathrm{KDI}$ 경제정보센터, 2017). 


\section{4. 개발도상국에 블록체인이 가져올 변화}

\section{1) 경제·사회· 정치 포용}

블록체인 시스템에서는 누구나 쉽게 계좌 개설이 가능하고, 스마트폰 없이 아주 소액의 거래 도 가능하며, 거래를 완료하는 데 비용이 거의 소요되지 않는다. 이러한 금융 서비스는 문맹 인구든, 계좌가 없는 여성들이라도 휴대폰이나 인터넷만 있다면 자산을 거래할 수 있도록 한다. 또 빠르고 저렴한 송금을 통해 가족 생계를 이어 나가고, 여유 자산을 비축해 미래를 설계할 수 있도록 해 준다.

금융포용은 결국 더 나은 교육, 보건, 여성의 권리 향상 등 사회경제 각층의 활력으로 이어진 다. 취약한 사회제도 문제를 해결하기 위해 블록체인 기술을 기반으로 한 재산권 보장 및 신분 등록의 도입 역시 사람들의 삶에 합법적 권한을 부여할 뿐만 아니라 정확하고 투명한 데이터를 기반으로 한, 아무도 소외받지 않는 정책 및 개발을 가능하게 한다(Schmidt and Sandner, 2017).

블록체인에 기반을 둔 예산 추적 메커니즘은 정부의 예산집행 내역에 대한 투명성을 확보해 부패를 방지하고 거버넌스를 확립한다(Schmidt and Sandner, 2017). 만일, 블록체인이 투표 시스템에도 활용된다면, 오랫동안 지속된 정치적인 부정부패로 어려움을 겪은 많은 저개발 국가에 서 모든 국민이 투명하게 참여할 수 있는 직접민주주의가 실현되는 발판이 되어 줄 것이다.

\section{2) 원조 투명성}

블록체인이 가장 시급하고 적극적으로 활용되어야 하는 분야는 바로 '사회적 사업'이나 '공적 원조(Official Developmet Aid, 이하 ODA) 사업’이다(Danida et al., 2017). 이 분야는 비용 이 발생하고 거래 관계가 존재하지만, 기존 시스템의 체계화나 투명화가 잘 이루어지지 않고 있기 때문이다.

국제연합(United Nation, 이하 UN)은 개발자금 가운데 약 $30 \%$ 가 중간 전달 과정의 부정부 패로 인해 사라진다는 점에 착안해 블록체인 기술을 기반으로 한 자금관리 시스템의 도입으로 자금 손실을 방지하는 데 성공한 바 있다. 유엔세계식량계획(World Food Program, 이하 $\mathrm{WFP})$ 은 이더리움 암호 화폐를 기반으로 한 블록체인 시스템을 활용해 시리아 난민을 지원하는 데 큰 성공을 거두었다. 향후 블록체인은 개발 및 인도주의 분야에서 가장 유망한 새로운 기술 도구 중 하나가 될 것이다. 


\section{How: 개발 분야에 블록체인은 어떻게 활용되는가?}

블록체인은 신뢰가 필요하고 또 투명성이 필요한 영역이라면 모두 응용이 가능하다. 그러나 개발도상국가의 부족한 기반 현실과는 괴리가 존재한다. 따라서 동 보고서는 SDGs 목표와 개발

도상국 현실에 비추어 가장 영향력이 있고 실행 가능성이 높은 분야를 문헌 연구를 통해 선정했다. 따라서 금융포용, 사회·공공 거버넌스, 인도주의적 지원의 세 분야에 대해 살펴보고자 한다.

\section{1. 금융포용(Financial Inclusion)}

1) 개발도상국의 경제 분야 선결과제: 금융 접근성 개선

SDGs 시대에 포용적 금융의 실현이 중요한 이유가 무엇일까? 금융 서비스의 접근은 모든 경제활동의 필수 조건이다. 금융 서비스의 접근을 통한 자산의 축적과 재산권 확보는 교육, 의료보건, 여성의 권리 신장, 사회 불평등 해소 등 전 분야에 걸쳐 사람들의 생활을 항상시키고 또 인간다운 삶을 살게 한다. 따라서 『블록체인 혁명』의 저자 댄 탭스콧(Tapstcott, 2018)은 금융 활동으로의 편입이 '인간의 기본권'이라고 표현하기도 했다.

하지만 전 세계 약 17 억 명 혹은 개발도상국의 성인 인구 $45 \%$ 는 여전히 계좌 개설이나 송금, 이체와 같은 금융 서비스에 여전히 접근할 수 없다(Mckinsey Global Institute, 2016). 은행 지점이 없는 지역에 살거나, 금융기관의 높은 신용 검증 절차를 통과할 여력이 없기 때문이 다. 아프리카, 중동, 동남아시아 및 남아시아에서 높은 비중으로 나타나며 특히, 빈곤층 못지않 게 여성 및 농촌 거주자들에게서도 높은 비율로 나타난다.

\section{2) 금융 접근성 개선을 위한 블록체인 활용}

기존의 엠페사와 같은 혁신적 디지털 결제 수단의 성공은 보다폰과 사파리콤이 기존에 지닌 수십만 개의 통신 대리점과 은행 인프라가 주요한 역할을 했다. 해외 송금 역시 전통 금융망보다 는 저렴하고 쉬운 송금 진입이 가능했지만, 여전히 전통적인 파이프라인을 통과해야 했다(케이 시·비냐, 2017)). 블록체인 네트워크는, 스마트폰이 아닌 기본적인 기능을 지닌 $2 \mathrm{G}$ 휴대폰만 있다면 네트워크 플랫폼에 접속할 수 있다는 점에서 접근성이 훨씬 더 넓어지고 또 진입 문턱이 낮아진다 (Danida et al., 2017). 따라서 전자지갑을 개설하는 것은 계좌 개설보다 훨씬 쉽다. 또한 아주 소액이라도 결제나 대출이 가능하며, 기존 금융망이나 이동 통신망을 활용하는 것이 
아닌 P2P 방식으로 진행하므로 수수료가 절감되고 또 신속한 자금 이동 및 가용이 가능해진다 (탭스코트, 2016)(<표 2> 참고).

\section{〈표 2〉 금융 분야 블록체인 실제 활용 시례}

\begin{tabular}{|c|c|}
\hline 송금 & $\begin{array}{l}\text { - 비트코인이나 리플과 같은 암호 화폐 기반으로 수수료 및 시간을 절감한 빠른 송금이 } \\
\text { 가능함. } \\
\text { [예] Bitpesa(아프리카 기반 송금), Bitmari(짐바브웨) 등. } \\
\text { 관련 SDGs 목표: 1(빈곤 종식), } 2 \text { (기아 종식), 5(양성 평등), } 10 \text { (국내 및 국가 간 불평등) }\end{array}$ \\
\hline $\begin{array}{l}\text { 은행 소외계층의 } \\
\text { 금융서비스 이용 }\end{array}$ & $\begin{array}{l}\text { - 은행 계좌가 없어도 대출을 받거나 투자를 할 수 있음. 현금 대출이 불가능하거나, } \\
\text { 가능하다고 하더라도 비공식적 금융의 높은 금리로 대출해야 하는 소기업이나 자영업 } \\
\text { 자들에 P2P 대출 서비스를 제공함. } \\
\text { [예] ETHLend (이더리움 네트워크를 기반으로 만들어진 분산화 된 P2P 금융 플랫폼, } \\
\text { Zper(국경 한계 없이 다양한 곳에서 암호 화폐로 대출 또는 투자 요청을 할 수 } \\
\text { 있는 P2P 금융 플랫폼) } \\
\text { - 블록체인 시스템은 온라인상에 존재하고 거래 인증 절차를 포함함으로써 수수료 절감 } \\
\text { 을 통해 개발도상국 국민들의 건강 및 생명보험 가입 가능. [예] Consuelo(멕시코의 } \\
\text { 블록체인 기반 소액보험 서비스) 등. } \\
\text { 관련 SDGs 목표: } 8 \text { (양질의 일자리와 경제성장), } 2 \text { (기아 종식), 1(빈곤 종식), } 5 \text { (양성 } \\
\text { 평등), } 10 \text { (국내 및 국가 간 불평등) }\end{array}$ \\
\hline $\begin{array}{c}\text { 농업 가치사슬 } \\
\text { 연계 }\end{array}$ & $\begin{array}{l}\text { - 가난한 소농과 직거래, 생산지 확인을 통해 직접 지급 가능한 시스템이 있음. } \\
\text { [예] Bext360(커피원두 농민들을 위한 블록체인 기반 직접지급 시스템) } \\
\text { 관련 SDGs 목표: } 1 \text { (빈곤 종식), 2(기아 종식), } 8 \text { (양질의 일자리와 경제성장), 9(산업, } \\
\text { 혁신 그리고 인프라 구축) }\end{array}$ \\
\hline $\begin{array}{l}\text { 소상공인 혹은 } \\
\text { 스타트업 금융 } \\
\text { 접근성 확보 }\end{array}$ & $\begin{array}{l}\text { - 기존 크라우드펀딩 플랫폼과 달리 블록체인 기반 크라우드펀딩 플랫폼은 스마트 계약 } \\
\text { 과 평판 관리 시스템을 통해 만들어지기 때문에 중개인이 필요 없어짐. 새로운 프로젝 } \\
\text { 트를 시작하려면 제품이나 서비스로 교화될 수 있는 토큰을 만들면 됨. } \\
\text { 관련 SDGs 목표: } 8 \text { (양질의 일자리와 경제성장) 9(산업, 혁신 그리고 인프라 구축) }\end{array}$ \\
\hline
\end{tabular}

출처: Danida et al. (2017)에 기반을 두고 각종 자료를 취합해 저자가 재작성

3) 해외송금 실제 사례 분석

(1) 전통 송금 방식

2016년, 대략 3,200억 달러의 송금액이 개발도상국에 보내졌으며, 이는 개발도상국에 매우 중요한 개발자금이다. 이 금액은 전체 공적개발원조(Official Development Assistance, 이하 ODA) 금액의 약 3배에 이른다(World Bank, 2016; World Bank, 2017; Pisa et al., 2017). 평균 200 달러 상당의 금액을 선진국에서 송금한다고 했을 때, 전 세계 송금 평균비용은 7.4 $\%$ 지만 지역마다 편차가 존재한다. 남아시아는 5.4\%이며, 아프리카는 송금수수료가 가장 비싼 지역으로서 $9.4 \%$ 에 달하기도 한다. 글로벌 공동체의 노력에도 불구하고, 지속가능개발목표인 3\%보다 약 4.4\% 이상 높은 수치다(World Bank, 2017; Pisa et al., 2017). 
일반적으로, 은행을 기반으로 한 송금 모델은 <그림 $6>$ 과 같이 크게는 국내 은행, 중개 은행 및 현지 은행의 3단계 구조를 거친다.

예를 들어, 해외 근로자가 케냐에 있는 가족에게 송금을 하면 국제은행 간 통신협정(Society for Worldwide Interbank Financial Telecommunication, 이하 SWIFT)을 바탕으로 해외

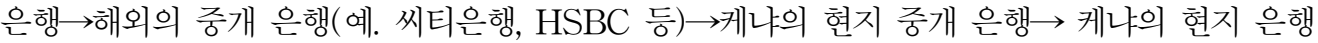
의 과정을 거친다.

송금수수료가 비싼 이유는 이 중개수수료와 SWIFT를 사용할 때마다 발생하는 수수료 때문 이다. 특히 개발도상국의 경우, 인프라가 열악하기 때문에 중개 은행이 더 늘어나게 되어 시간은 더 소요되고 또 비용은 더 높아진다.

〈그림 6〉 은행을 기반으로 한 송금 모델

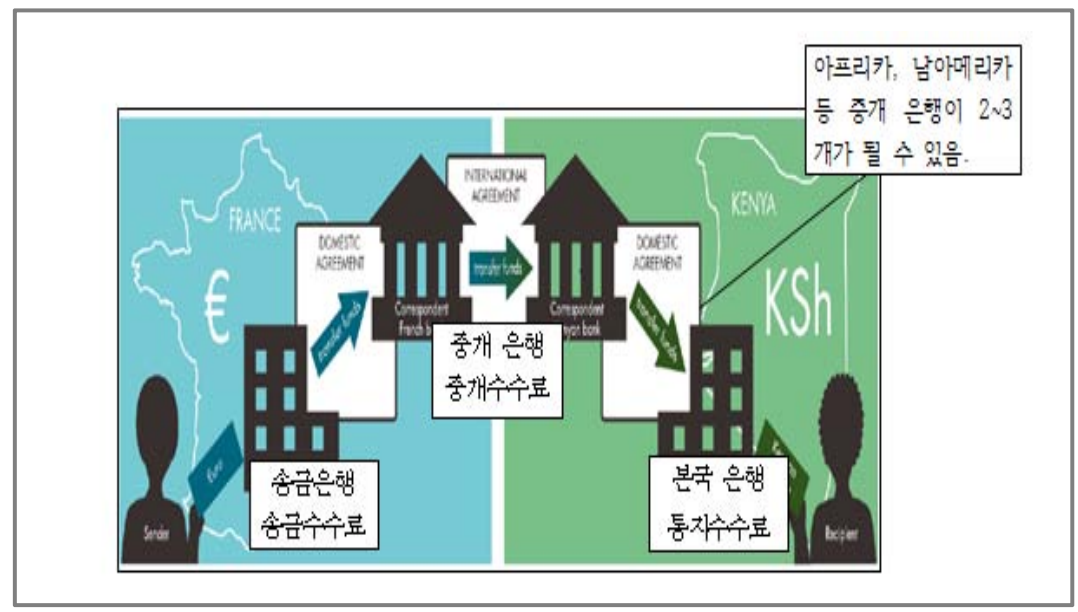

출처: Pisa and Juden (2017)

(2) 암호화폐 송금 방식

기존 송금의 높은 수수료율과 비효율적인 프로세스를 개선하고자 암호 화폐를 기반으로 한 송금서비스가 속속 등장하고 있다. 그 중 개발 분야에서 대표적으로 언급되는 암호 화폐 기반 송금서비스인 비트페사(Bitpesa), 리플(Ripple) 그리고 스텔라(Stellar)에 대해 알아보고자 한다.

아프리카 비트코인 송금 서비스인 비트페사(Bitpesa)는 송금에 있어 전통적인 은행 시스템 이 아닌 비트코인을 통해 이루어진다. 해외 송금 시 $1 \sim 3 \%$ 의 고정 수수료만 받는다. 비트페사 
(Bitpesa)는 비트코인 기반의 송금 서비스가 국제 송금 비용을 $90 \%$ 줄이고, 결제 평균 시간을 2 14일에서 약 1 24시간으로 단축한다고 한다. ${ }^{8)}$

은행이 송금 서비스를 하려면 최소 100 만 달러 정도를 투자해 시스템을 정비해야 한다(케이 시·비냐, 2017). 하지만 비트코인과 블록체인은 그 자체가 변경 불가능한 장부이므로, 다른 절차 없이 사용만 하면 되기에 인프라와 자본이 부족한 아프리카에 최적화되었다고 볼 수 있다.

리플(Ripple)은 태생부터가 비트코인과 다른 프라이빗 블록체인 형태를 띤다. 쉽게 말해, 블록체인 응용프로그램을 기존 은행 시스템에 도입해 효율화를 꾀한 것이다. 은행 간 외환 거래 시 SWIFT망을 기반으로 하는데, SWIFT라는 이름과 다르게 이 망은 느리고 비효율적이 다. 리플은 이를 대체하는 결제 프로토콜이다(한승환, 2017).

이 네트워크는 일종의 외환 거래(Foreign Exchange) 역할을 한다. SWIFT 망 내에서의 결제는 2 10일이 소요되지만, 리플 네트워크는 10초면 충분하다. 더욱이 리플을 매개로 전 세계 각 국가의 화폐를 단 몇 초 내에 송금할 수 있어 실시간 통화 거래가 가능하다(<그림 7>참고).

리플 공식 홈페이지9)에 의하면, 리플 활용 시 글로벌 송금 비용 300억 달러 중 55\%인 165 억 달러를 절감할 수 있다고 한다. 인도, 중국, 필리핀, 멕시코, 파키스탄 등 송금 비중이 높은 5 개 국가에 대한 송금 도달 지역의 생활수준을 조사한 결과, 165 억 달러를 절감하면 32 억 7 천만 번의 끼니를 제공할 수 있으며(1인당 평균 4.13 달러로 계산), 2 억 6,300 만 명의 한 달 생활비(1인당 평균 생활비 51.32 달러로 계산) 4,990만 명의 주거비용(평균 273.34 달러로 계산)를 대체할 수 있다(Team Ripple, 2018).

스텔라(Stellar)는 리플에서 분사되어 나온 블록체인 기술로, 리플과 같은 네트워크를 사용 하고 있지만 $\mathrm{P} 2 \mathrm{P}$ 거래, 특히 금융 소외 계층을 위한 서비스 제공을 목표로 한다. 즉, 금융 인프라가 잘 형성되어 있지 않은 개발도상국에 중점을 두고 확장해 나가고 있다(원재연, 2018). 지난 2016년, 스텔라는 나이지리아의 은행에서 해당 시스템 구축 로드맵을 최초로 발표한 데 이어 필리핀, 인도와 제휴를 맺고 아프리카 은행 간의 거래 프로젝트에 참여하고 있다(원재 연, 2018).

8) 자세한 내용은 비트페사(Bitpesa) 홈페이지를 참조하기 바란다. (https://public.bitpesa.co/) (접속일:2018. 7. 10.) 9) 리플 홈페이지는 다음과 같다. 홈페이지 주소 : https://ripple.com/insights/democratizing-global-paymentsxrapids-cost-savings-benefits/ (접속일: 2018. 7. 2.) 
〈그림 7〉 송금 네트워크 비교

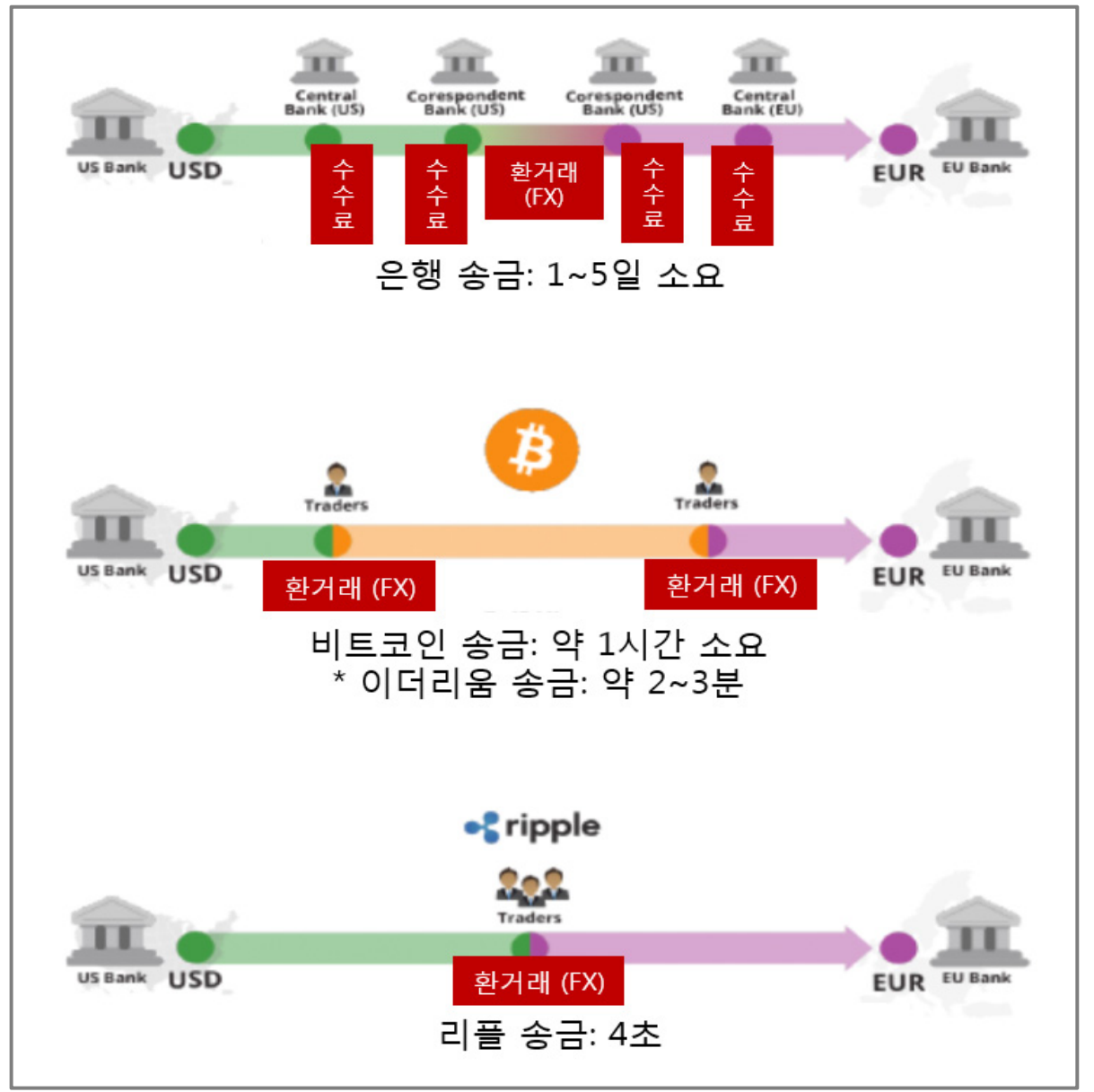

출처: Ripple 홈페이지 (https://ripple.com) (접속일: 2018.07.02.)

본래 개인 송금 서비스로 시작한 비트페사는 사하라 이남 아프리카의 송금 이익이 너무 적어서 $\mathrm{B} 2 \mathrm{~B}$ 송금으로 비즈니스 모델을 변경했다. 그러나 국경 간 지급을 위한 가교로 비트코인 을 사용하는 것은, 암호 화폐 자체의 변동성 문제와 $\mathrm{B} 2 \mathrm{~B}$ 전통 송금 업체의 벽을 뛰어넘지는 못하고 있다. 즉, 많은 사람이 기대했던 만큼은 영향력을 갖지 못하고 있는 실정이다.

리플은 프라이빗 블록체인으로 매우 빠르고 효율적이지만, 검증 노드가 제한적이므로 검증 노드에 대한 신뢰가 필요하다. 현재 리플사는 자체적으로 개발한 XRP 화폐를 기반으로 빠른 환거래가 가능토록 하고 있으며, 이 화폐의 $60 \%$ 를 본사가 소유하고 있다. 이에 따른 독과점에 대한 시장 교란도 무시할 수 없는 사안이다. 리플 역시 암호 화폐에 대한 불안정성을 무시할 수 없다. 


\section{2. 사회 · 공공 거버넌스 개선}

1) 개발도상국 사회 · 공공 분야의 선결 과제 : 신원 증명과 재산권

개발도상국에는 송금과 계좌 개설보다 더 근본적으로 해결할 아주 중요한 정책적 선결 과제 가 있다. 이는 명확한 재산권 보호 문제다(케이시·비냐, 2017). 대부분의 개발도상국은 재산권을 보장하는 거버넌스 체제가 전반적으로 취약하고, 합법적 부동산 등기소와 증빙문서 체계가 부족하다. 또한 대부분의 빈곤층은 주택이나 사업 등을 정당하게 소유하고 있지만 대출, 투자를 받거나 경제활동에 참여하는 것이 어렵다. 2013년 아프리카의 농촌 $90 \%$ 이상이 문서화되지 않은 채로 남아 있고, 적절한 토지소유권에 접근하지 못하고 있다는 것이다(Nir Kshetri et al., 2018).

신원(Identification) 증명이 가능하고, 각종 세금 및 교육·의료 등의 다양한 데이터가 기록되 고 열람이 가능한 공공 서비스 플랫폼은 소외 계층들의 삶을 사회로 편입시킬 수 있게 한다 (Schmid and Sandner, 2017). 이는 지속가능개발에 필수적인 요소다. 신원증명서가 없는 것은 저개발국에서 흔히 발생하는 문제다. 약 11 억 국민들이 신분증이 없다고 알려져 있다 (GSMA, 2017). 이는 은행 계좌 개설과 같은 경제활동은 물론 교육, 의료 혜택, 참정권 또는 정부 서비스 등 국가 내에서 기본적으로 누려야 할 사회적 권리를 보장받을 수 있는 기회를 제한한다.

\section{2) 사회 · 공공 서비스 분야의 개선을 위한 블록체인 활용}

블록체인 기술은 신분증, 운전면허증, 출생 또는 혼인신고서와 같은 기본 신원과 지위를 등록 할 수 있는 원장을 만들어 종합 신원 관리를 가능하게 한다. 또한 각종 사회보장 및 보험 혜택의 사각지대에 소외받지 않도록 하는 기능을 한다.

인구통계자료 없이 교육 프로그램을 수립하거나 사망 원인에 대한 정보 없이 전염병을 예방 하는 것은 불가능하다. 정확한 신원 확인은 사람들이 사회경제적 활동을 비롯한 다양한 활동에 참여하게 하며, 올바르고 정확한 정보를 보장함으로써 기업이나 정부기관 및 원조기구에 더 큰 신뢰를 보장한다.

블록체인 기술의 타임스탬프 기능은 데이터의 정확성이나 투명성 및 보안을 보장하므로, 공공데이터를 활용하는 서비스에서 빛을 발할 것이다. 실제로도 전 세계의 많은 정부가 건강 기록, 투표, 세금, 복지 수당부터 시민 및 디지털 통화에 이르기까지 모든 것에 대한 새로운 
시스템을 만들기 위해 분산 원장에 공공서비스를 제공하면 어떨지를 자세히 조사하고 있다(민 대홍 외, 2018).

\section{〈표 3〉사회 공공서비스 분야의 블록체인 활용 시례}

제I장

\section{제II장}

도시와 사회), 16 (평화·정의 제도 구축), 17 (목표를 위한 파트너십)

- 블록체인을 이용하게 되면 $\mathrm{ID}$ 를 발급받는 것만으로도 신분을 증명할 수 있게 됨. 난민은 타국 에서 신분 증명을 통해 지위와 자산을 보장받을 수 있으며, 개발도상국의 경우에는 위조가 불가능한 블록체인 신분 증명을 통해 신분 증명이 제대로 되지 않아 발생할 수 있는 인신매매 와 장기매매 등을 방지할 수 있음.

[예] 에스토니아 'e-residence', UN \& World Identity Network, 유엔세계식량계획(World Food Programme, WFP) Building Blocks 의 홍채 인식 신분 확인.

신원 확인

(ID)

[예] ID 2020 프로젝트: 법적 신원 확인 문제로 선거, 의료보험, 주거, 교육 등 기본권을 보장받 지 못하는 사람들을 위한 디지털 신원 시스템 개발, 글로벌 프로젝트로 영국의 DFID와 Microsoft 등 다양한 기관이 공동 참여하고 있음.

관련 SDGs 목표: 1(빈곤 종식), 2(기아 종식), 3(건강 및 웰빙), 4(양질의 교육), 5 (양성 평등), 6(물과 위생), 8 (양질의 일자리와 경제성장), 10 (국내 및 국가 간 불평등), 11 (지속 가능한 도시 와 사회), 16 (평화·정의 제도 구축)

- 보건 기록을 블록체인에 저장해 민감한 의료 데이터를 보호함과 동시에 기관 간 데이터를 공유함. [예] 진료 영상 데이터와 같은 의료정보를 환자가 여러 병원에서 쉽게 이용할수 있도록 하는 국내 의료 블록체인 기업 메디블록(Mediblock)

의료 분야 - 개발도상국의 의약품 중 $30 \%$ 가 위조품이라고 함. 블록체인을 활용해 위조 의약품 방지가 가능함.

관련 SDGs 목표: 3(건강 및 웰빙), 6 (물과 위생), 16 (평화 - 정의제도 구축), 17 (목표를 위한 파트너십 구축)

- 농산물 생산자나 생산지, 시장가격은 물론 누가 얼마에 구매했는지 등의 정보가 블록체인에 의해 기록되므로 직거래가 가능하며, 거래에 있어 중개수수료가 발생하지 않음. 농가에도 소비자에게도 부담이나 손실 없는 거래가 보장되며, 안전한 식품 공급망을 확립할 수 있음.

유통망 관리 [예] Bext360, Provenance, 경기도 인증 우수농특산물 인증마크(G 마크) 발급에 블록체인 활용.

관련 SDGs 목표: 1(빈곤 종식), 2(기아 종식), 5(양성 평등), 8(양질의 일자리와 경제성장), 9(산업, 혁신 그리고 인프라 구축), 12(책임 있는 생산과 소비)

- 등기 서류 및 소유권은 물론 금융, 무역 등 모두 소프트웨어로 제어가 가능하도록 입력됨. 계약상 의무 조건이 충족되면 자동으로 실현되는 계약으로 비즈니스, 공공서비스뿐만 아니라 원조기금을 전달하는 데도 활용.

스마트계약 [예] Building blocks 세계식량계획의 분쟁지역 신속하고 안전한 구호물자 지원 프로그램 관련 SDGs 목표: 8(양질의 일자리와 경제성장), 9(산업, 혁신 그리고 인프라 구축), 10(국내 및 국가 간 불평등), 11 (지속 가능한 도시와 사회), 1 (평화 - 정의 제도 구축), 17 (목표를 위한 파트너십 구축) 


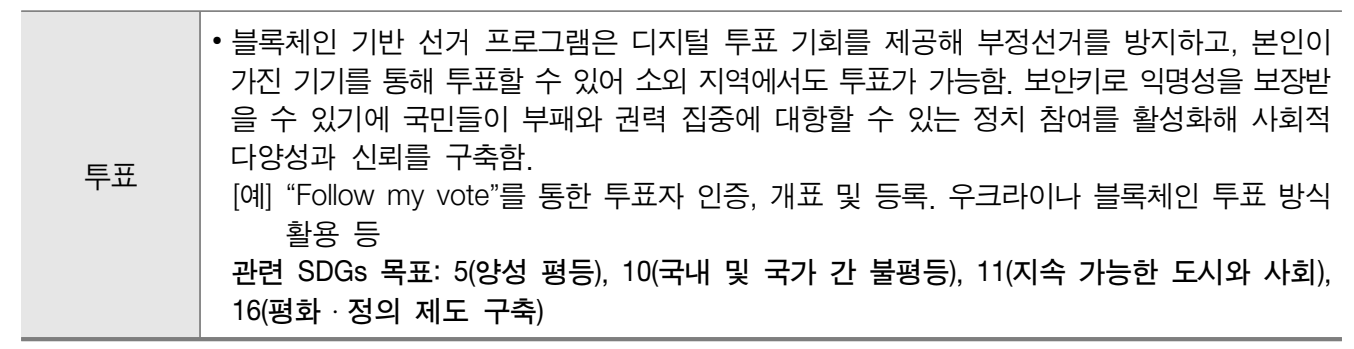

출처: Danida et al. (2017). "Hack the aid"; 민대홍 외 (2018) 내용을 참고해 저자가 재구성

\section{3) 토지 등록 실제 사례 분석}

온두라스는 부정부패로 유명한 국가다. 2016년 기준으로 부패인식지수는 180 개국 중 123 위 로 나타났다. 특히, 토지대장의 조작과 관련된 부패가 가장 심하다(유성민, 2017; Nir Kshetri et al., 2018; Pisa et al, 2018). 지방 토호와 군벌이 농민들 토지를 강제로 빼앗는 등 문제를 일으키고 정부 관료까지 조작하는 불법을 자행했기 때문이다(유성민, 2017).

온두라스는 2015년에 블록체인 업체인 팩텀(Factom)과 협약해 국가 토지대장을 블록체인 상 분산원장에 기록하고 있다(이명환, 2016). 토지대장을 블록체인으로 관리하면, 한 번 저장된 토지 내역은 관리들에 의한 위·변조가 불가능하다. 아울러 토지 내역이 모두 공유되기 때문에 투명하다. 따라서 블록체인을 공공서비스에 적용하면, 서비스의 신뢰성을 향상시키는 것은 물론 많은 이의 재산권을 보호할 수 있을 것이다.

가나는 $78 \%$ 의 토지가 등록이 되지 않은 상태이며, 가나 법원에는 토지 분쟁 사건이 산적해 있다고 한다. Bitland는 토지 등록 및 소유를 위한 블록체인 기반의 부동산 플랫폼 스타트업이 며, 2016년 중반 현재 가나의 24개 지역사회가 Bitland와 합작해 부동산 등록 프로젝트에 동참했다(Nir Kshetri et al., 2018).

인도에서는 토지 등기를 유리하게 기록해 주는 대가로 공무원이 받는 뇌물이 7억 달러(한화 약 7,584억 원)에 달한다고 한다(Danida et al., 2017). 인도 정부는 이런 상황을 개선할 방책으 로 블록체인을 활용하고자 하며, 인도 Telangana와 Andhra Pradesh 주정부는 스웨덴 스타 트업 ChromaWay와 연계해 토지 등록에 블록체인을 활용할 계획을 가지고 있다(Nir Kshetri et al., 2018). 


\section{3. 인도주의적 지원}

1) 인도주의적 지원의 선결 과제: 신속성과 투명성 확보

제I장

2012년, 반기문 전 UN 사무총장은 UN 연설에서 UN의 집행 자금 가운데 약 $30 \%$ 가 비효율 적인 프로세스와 부정부패로 인해 사라지고 있다고 언급했다(Danida et al., 2017). 실제로 원조자금은 은행 수수료, 환율 변동 등 이동 시 많은 부대 비용이 소요된다. 또한 개발원조는 빠르게 변화하고 있지만, ODA의 움직임은 느리다(Danida et al., 2017; GSMA, 2017). 위기 대응에 있어서도 자금 이동이 몇 주가 걸리는 실정이다. 또한 수원국 지방 관리나 원조기구 중간 관리자 단계에서 자금 횡령이 일어나더라도 추적이 어려우므로 개발 자금은 때때로 개발도 상국 부정부패의 산물이 되고 있다. 따라서 원조의 영향력은 필연적으로 감소할 수밖에 없다. 필요한 지역사회와 개인에게 제대로 전달되기 위해서는 신속하고 투명한 프로세스가 확보되어 야 한다.

\section{2) 인도주의적 지원 분야의 블록체인 활용}

블록체인 기반의 응용 프로그램은 모든 거래 기록을 저장하고 집행 내역을 추적할 수 있다. 블록체인은 데이터(예. 계좌번호, 거래 시간, 거래 금액, 수신자)가 기록되면 관련 내역이 영원히 기록되고, 위·변조가 불가능하므로 정부 혹은 원조 기관의 집행·지출을 추적하고 또 예산 분석 을 실시할 수 있다(Schmidt and Sandner, 2017). 블록체인 시스템은 부정부패에 강할 뿐만 아니라 정확한 최신 데이터를 실시간으로 확인할 수 있다. 이더리움(Ethereum) 암호 화폐에 기반을 둔 스마트 계약은 블록체인 1.010)에서 블록체인 2.0으로 진화된 기술 형태이며, 전 산업 분야에 응용이 가능하다. 스마트 계약은 소유권 이전이나 조건 실행 시 자동으로 계약이 실행되는 알고리즘을 의미한다. 원조자금 집행에 도입한다면, 전자신원인증과 특정 조건 충족 시 계약이 자동 실행되어, 불필요한 행정비용 및 수수료를 절감해 신속한 이행을 가능하게 할 것이며, 또한 자금을 투명하게 집행할 수 있을 것이다.

쉬운 예로, 원조 기관과 잠재적인 수원국의 지역이 자연재해의 영향을 받는다고 할 때, 계약은 기상 서비스가 제공한 데이터를 기반으로 자동으로 실행되도록 할 수있다(Pisa et al., 2017). 이러한 방식은 원조 기금 분배의 속도와 투명성을 증가시킬 것이다.

10) 블록체인 1.0 은 1 세대 블록체인 기술이라고 부르며, 암호 화폐, 결제, 송금 등이 가능한 블록체인 기술 단계를 뜻한다. 2.0은 스마트 계약을 필두로 한 비즈니스 효율성을 핵심으로 한다. 3.0은 정부, 사회 및 공공 거버넌스 전반의 연결까지 확장된다. 
또한 블록체인은 비정부기구(Non-Governmental Organization, 이하 NGO)나 자선단체 의 투명하고 세밀한 자금 집행을 가능하게 한다(Nir Kshetri et al., 2018). 이는 사람들이 더 많은 기부를 할 수 있도록 장려한다. 한편, 우시조(Usizo)는 누구나 전자화폐를 지불함으로 써 공동체 학교에 도움을 줄 있도록 하는 남아프리카 기반의 블록체인 플랫폼으로서 기부자들은 학교가 얼마큼의 전기를 소모하는지 추적할 수 있고, 기부금으로 어느 정도의 전력을 공급할 수 있는지 계산할 수 있다(Danida et al, 2017).

\section{3) 원조 지원 플랫폼 실제사례 분석}

최근 WFP는 지난 5월 시리아 난민 지원에 '빌딩 블록스(Building Blocks) 프로젝트'를 시범 적용했다. 기존에는 은행이 특정 난민의 신용을 보증하면, WFP가 자금을 지원하고 해당 난민이 현지 상점에서 물품을 구입하는 형태였다. 자금 지원은 현지 은행과 협업이 필요했고, 국경 간 자금 이동은 과도한 수수료를 동반했다(신버들, 2018).

$\mathrm{WFP}$ 는 이더리움 블록체인 네트워크에 난민의 가상 계좌를 만들어 암호 화폐 형태의 바우처 를 지급한다. 난민캠프 슈퍼마켓에서 물품을 고른 난민은 계산대에 설치된 홍채스캐너를 통해 유엔난민기구(UN Refugee Agency, UNHCR)의 난민 데이터베이스에 등록되었는지 확인 절차를 거치며(Bayram, 2018), 이를 통해 해당 난민의 바우처가 확인되면 결제가 진행된다 (<그림 $11>$ 참조).

$\mathrm{WFP}$ 는 빌딩 블록 프로젝트로 총 1만 명의 시리아 난민을 지원했으며, 2018년 말까지 요르단 에서 10 만 명을 추가 지원할 계획이다(신버들, 2018). WFP의 뮌헨 혁신연구소의 베른하르트 코와치(Bernhard Kowatsch)는 “은행 관련 비용의 $98 \%$ 를 절감하면서 이번 시범 운영에만 매달 15만 달러(한화 1 억 6,000만 원)가 절약됐다”고 밝혔다(권승원, 2018; 하이레, 2018).

빌딩 블록스(Building blocks) 프로그램의 의의는 단순한 재정적 지원이 아니다. 이는 신원 확인이 어려워진 난민들에게 효율적인 신원 확인을 제공할 뿐만 아니라 신원 확인을 통한 신분 회복으로 난민들이 다시금 경제적·법적 시스템 안에서 안정적인 삶을 살 수 있도록 해 준다는 데 의의가 있다(Bayram, 2018). 
〈그림 11〉 빌딩 블록스(Building blocks) 프로그램

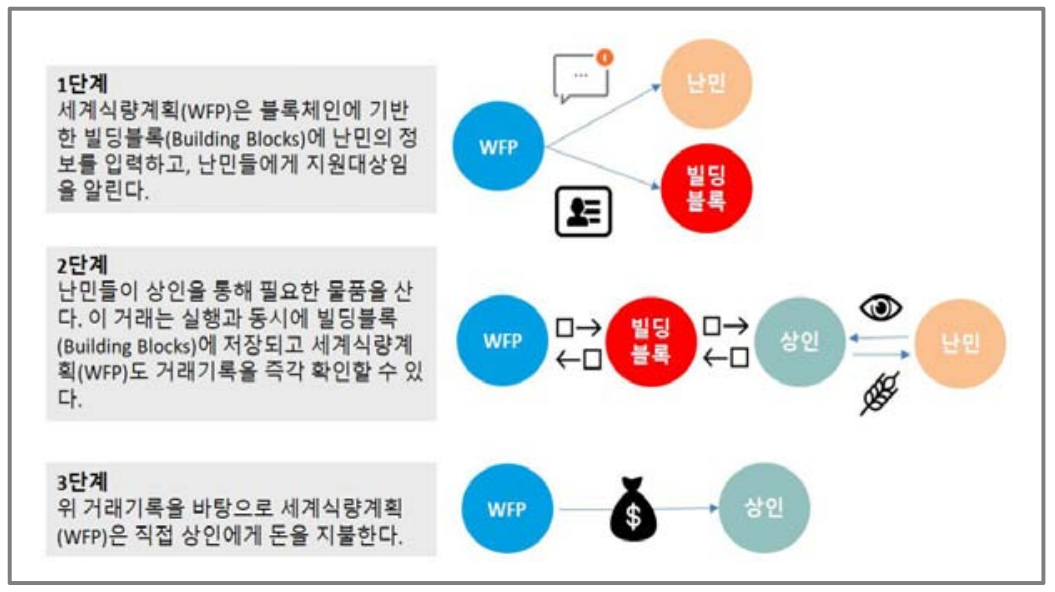

출처: GMSA (2017); 이진욱 외 (2018)

$\mathrm{WFP}$ 외에도 UN은 현재 가장 활발하게 블록체인 기술을 개발하고 있다. 난민을 대상으로 한 현금 지원(Cash transfer)뿐만 아니라, 아동 인신매매나 자산관리에 이르기까지 블록체인 기술에 대한 연구가 한창이다(<표 4>참고).

\section{〈표 4〉UN 기구의 블록체인 활용 시례}

\begin{tabular}{|c|c|c|}
\hline 다자원조기구 & 사례 & 내용 \\
\hline $\begin{array}{l}\text { UNOPS 외 } \\
70 \text { 개 원조기구 }\end{array}$ & $\begin{array}{l}\text { 블록체인 기반 단일 } \\
\text { 다자원조기구 플랫폼 도입 }\end{array}$ & $\begin{array}{l}\text { 원조자금 전달의 효율성 제고, 블록체인 기반 국 } \\
\text { 제원조 자금 관리 }\end{array}$ \\
\hline WFP & 아즈락(Azraq) 난민 현금 지원 프로그램 & $\begin{array}{l}\text { 현금 지원 시 수수료를 줄여 거래비용 절감, 난민 } \\
\text { 들의 신분 증명, 정보 보안 향상 }\end{array}$ \\
\hline UNICEF & $\begin{array}{l}\text { 남아프리카 아동 신원인증 프로젝트 } \\
\text { (Project Amply) }\end{array}$ & $\begin{array}{l}\text { 정확하고 신뢰성 있는 데이터를 통해 ODA 사업 } \\
\text { 의 예측 가능성 향상 }\end{array}$ \\
\hline UNHCR & $\begin{array}{l}\text { 홍채 인식을 활용한 아동 신원인증 } \\
\text { 시스템(ID system) 도입 }\end{array}$ & $\begin{array}{l}\text { 신원 정보의 조작 위험 없이 정확한 원조물자 배 } \\
\text { 분. 신원 인증 과정의 불필요한 절차 생략. ODA } \\
\text { 사업 전 과정의 비용 절감 }\end{array}$ \\
\hline UNFCCC & 기후체인연합(Climate Chain Coalition) & $\begin{array}{l}\text { 탄소배출권 거래, 클린 에너지의 P2P(peer-to- } \\
\text { peer) 거래, 기후 재원에 대한 관리, 온실가스 배 } \\
\text { 출량 추적 }\end{array}$ \\
\hline UN Women & 블록체인을 통한 성평등 제고 & $\begin{array}{l}\text { 디지털화된 자산 직접 관리해 시민권과 경제적 } \\
\text { 정체성 확보 }\end{array}$ \\
\hline WIN, UNOPS & 아동 인신매매 퇴치 & $\begin{array}{l}\text { 아동의 신원 보증을 통해 인신매매 퇴치, 인신매 } \\
\text { 매범 검거 }\end{array}$ \\
\hline
\end{tabular}




\begin{tabular}{|c|c|c|}
\hline 다자원조기구 & 사례 & 내용 \\
\hline UNDESA & $\begin{array}{l}\text { 지속가능개발을 위한 블록체인 활용법 } \\
\text { 연구 }\end{array}$ & 블록체인 기술을 활용한 송금 산업의 민주화 \\
\hline ECLAC & $\begin{array}{l}\text { 캐리비언 금융시스템 경감 조치에 대한 } \\
\text { 해결책으로서 블록체인 기반 정산 프레 } \\
\text { 임워크의 전망 연구 }\end{array}$ & $\begin{array}{l}\text { 블록체인 기술을 은행의 경감 조치 퇴치, 거래비 } \\
\text { 용 감소, 감시 수단으로 활용 가능성 제시 }\end{array}$ \\
\hline $\mathrm{OCHA}$ & $\begin{array}{l}\text { 〈인도주의적 블록체인 기술의 활용〉 보 } \\
\text { 고서 출판 }\end{array}$ & $\begin{array}{l}\text { 블록체인 기술의 적용 효과를 } 6 \text { 가지로 분류해 분 } \\
\text { 석 }\end{array}$ \\
\hline
\end{tabular}

출처: 이진욱 외 (2018); Heather Starkie (2017) 내용을 참고해 저자가 재구성

\section{4) 응용 사례 : 북한 원조 지원에 블록체인 기술 도입 논의}

대북 인도적 지원 시 블록체인을 활용해 보자는 논의가 대두된 적이 있다. Building Blocks 프로그램을 응용해 북한 주민 가상계좌로 바우처를 보내 북한 주민들이 현지 종합시장에서 식량을 구입하자는 것이다(신버들, 2018).

또한 블록체인을 활용해 북한 원조물자 정보를 추적할 수도 있다. 의약품을 보낼 때 지원국 발송 담당자, 지원국과 북한 측 운송 담당자, 물품을 수령한 북한 주민이 휴대전화 앱을 통해 물품 발송, 운송, 수령 시 블록체인에 이를 기록해 투명하고 적재적소의 인도주의 지원이 가능하 도록 한다는 것이다(신버들, 2018).

그러나 북한 내 은행 인프라 파악, 인구 등록, 핸드폰 보급 및 인터넷 활용 등 북한의 인프라와 거버넌스 체제를 고려했을 때 넘어야 할 산이 많아 보인다. 그러나 남북경협의 긍정적 기류가 가속화되고 있는 지금 현실에서는 아예 불가능한 상상은 아닐 것이다. 향후 국제기구의 주도로 국내 기관과의 합작을 통한 접근도 고려해 볼 수 있지 않을까 기대해 본다. 


\section{V. 결 론}

전세계적으로 블록체인 플랫폼이 꼭 필요한지, 세상의 소외된 자들에게 정말 도움을 줄 수 있는지에 대한 의구심이 높다. 2017년을 강타한 비트코인의 열풍과 하락은 블록체인 및 암호 화폐가 자본주의 확장을 위한 투자 수단인지, 더 나은 세상을 만들고자 하는 플랫폼인지 혼란스 럽게 한다.

블록체인은 암호 화폐 기술로 탄생했지만, 타 기술에 대한 기반기술이자 응용기술로서 모든 영역에 활용될 수 있다. 기본적으로 블록체인 기술은 사물인터넷, 빅데이터 등 4 차 산업혁명에 있어 주요 기술의 기반이 되는 보안기술이다. 따라서 개발도상국의 경우, 이 기반기술이나 블록 체인 생태계가 구축되어 있다면 4차 산업혁명에서 낙오되지 않을 뿐만 아니라 응용기술을 통한 도약 가능성이 열려 있다.

블록체인과 암호 화폐는 은행조차 없던 개발도상국 시민들에게 금융 접근성을 높여 준다는 점에서 1차적으로 그 가능성을 긍정적으로 평가할 수 있다. 만일 블록체인 기술이 스마트 계약, 전자정부시스템 및 인도주의 원조에 이르기까지 사회 전반에 '잘' 적용된다면 소외 계층들은 기존 사회제도에 빠르게 편입해 인간의 기본 권리와 다양한 사회보장 혜택을 누릴 수 있게 될 것이다. 또한 부정부패가 블록체인 기술의 보완성과 투명성으로 원천 봉쇄되고 또 원조 기관 및 정부 예산의 추적이 가능하게 된다면, 필요한 수혜자에게 원조가 적절하고 투명하게 전달될 것이다. 이 모든 것이 동시에 이루어질 수 있는 기술이 블록체인이라면, "Why not do it?'이라고 질문하고 싶다.

단, 블록체인 기술은 아직 초기 단계의 기술이다. 2 세대 블록체인인 이더리움의 창시자 비탈 릭 부테린(Vitalik Buterin)조차 현재 이더리움의 완성도는 30\%에 그친다고 한다(김열매, 2018). 그러므로 현재 사회·정치·경제를 아우르는 3 세대 블록체인의 경우에는 아직 개념 설계 단계이며, 테스트 단계에 불과하다. 수많은 스타트업 기업이 탄생하고 사라지고 있으며,11) 기술 적 난제들이 산적해 있다. 이보다 어려운 것은 이를 상용화해 하나의 생태계를 만드는 일이다. 법적 규제와 기존 사회질서와의 조화 등 국가 근간을 변화시켜야 하는 과제들 역시 기술 도입을 더디게 만드는 이유 중 하나다.

블록체인 기술은 엄청난 잠재력과 올바른 가치를 가지고 탄생했지만, 기술은 단지 가치 중립

11) 딜로이트는 2017년 10월, GitHub에 올라와 있는 블록체인 프로젝트 8 만 6 천여 개 중 약 $8 \%$ 만이 관리되고 있는 중이며, $5 \%$ 정도만이 생존할 것이라고 전망한다(김열매, 2018). 
적 수단일 뿐 기술 자체가 생명력을 가지고 세상을 변화시킬 수는 없다. 결국, 이는 사람의 손에 달렸다. 그것을 어떻게 활용하느냐가 블록체인이 4차 산업혁명 시대에서 승자 독식을 위한 도구가 될 것인지, 아니면 SDGs 달성의 가속화를 이루어 낼 포용적인 도구가 될 것인지를 결정할 것이다. 따라서 지속 가능한 미래를 위해 이 기술을 어떻게 활용할 수 있는지에 대한 더 깊은 수준의 연구와 실험이 반드시 필요하다.

이제 승자 독식의 시대인 4 차 산업혁명의 미래가 눈앞에 다가왔다. 전 세계는 앞으로 점점 더 지속가능개발에 대한 딜레마에 부딪힐 확률이 높다. 사회 내 신뢰할 수 있는 안전망과 민주적 이고 평등한 기반이 존재하지 않는 이상 선진국-개발도상국의 간극은 점점 커질 테고, 지속가능 개발의 달성은 수조 원의 공적개발원조에도 그 결과가 모래알처럼 흩어져 버릴 것이다.

앞서 살펴본 바와 같이 블록체인 기술이 개발도상국의 어려운 현실 과제에 응용되어 SDGs 달성을 가속화시킬 가능성은 무궁무진하다. 향후 이 기술이 가능성에서 머무는 것이 아니라 정치·경제·사회 문화 기반에 있어 누구에게나 평등한 기회와 정보를 제공하는 플랫폼의 역할을 실제로 수행할 수 있게 되는 날을 조심스레 고대해 본다. 


\section{참고 문헌}

금융보안원 보완연구부. 2015. 『블록체인 및 비트코인 보안기술』. 용인: 금융보안원. 김성준. 2017. 『블록체인 생태계 분석과 시사점』. 서울: 한국과학기술기획평가원. 김열매. 2018. 『블록체인 이상과 현실, 어디쯤 와 있나』. 서울: 한화투자증권. 김진화. 2016. 『블록체인(Block Chain)이 바꿀 미래』. 경영인사이트 비즈니스 라운지. 노르베리 호지, 헬레나(Norberg-Hodge, Helena). 2012. 『행복의 경제학: 경쟁과 양극

화를 넘어 더불어 사는 사회를 위한』. 김영욱·홍승아 역. 서울: 중앙북스.

민대홍·박종현·최선미·허필선·김헌진·민수진·박경진·송근혜·조진실·최가은. 2018. 『블

록체인, 어디에 응용하고 있나? - 응용 사례와 분야별 특성을 중심으로 -』. 대전:

전자통신연구원.

박성준. 2018. “블록체인의 미래.” 창조경제연구회 제44회 공개포럼 (2018.02.27., 카이스

트 도곡캠퍼스).

방태웅. 2018. 『4차 산업혁명의 기반기술, 블록체인』. 서울: 한국과학기술연구원 융합연 구정책센터.

슈밥·클라우스(Schwab, Klaus). 2016. 『클라우스 슈밥의 제4차 산업혁명』. 송경진 역. 서울: 새로운현재.

윤유리. 2017. “제4차 산업혁명과 국제개발협력의 미래."『개발과 이슈』: 29호:1-23.

성남: 한국국제협력단.

이경상. 2017. “I. 4차 산업혁명 시대, 역동적 기회의 창이 열린다.” 서울: 임베디드소프 트웨어·시스템산업협회.

이대기. 2017. 『블록체인의 활용과 규제 현황』. 서울: 한국금융연구원.

이민화. 2018. “블록체인의 국가전략." 창조경제연구회 제44회 공개포럼(2018. 02. 27., 카이스트 도곡캠퍼스).

이영환. 2016. 『국내외 블록체인 기술 적용 분야 및 사례연구』. 나주: 한국인터넷진흥원. 이제영. 2017. 『블록체인(Blockchain) 기술동향과 시사점』. 세종: 한국과학기술정책연구원. 임명환. 2016. 『블록체인 기술의 활용과 전망』. 대전: 한국전자통신연구원.

. 2018. “블록체인 활용과 암호화폐 경제.” $\mathrm{KCERN}$ 제 44 회 공개포럼 블록체인의 국가전략 (2018.02.27.) 카이스트 도곡캠퍼스.

케이시·비냐(Michael J. Casey and Paul Vigna). 2015. 『블록체인 2.0』. 유현재 외

1 명 역. 서울: 미래의 창.

탭스코트, 돈(Tapscott, Don). 2016. 『블록체인 혁명』. 박지훈 역. 서울: 을유문화사. 
이진욱·이채린·김민지. 2018. "블록체인을 활용한 국제개발협력 : 다자원조의 사례 분석 과 양자원조의 투명성 제고 모형.”『제 15 회 한국국제협력단 논문공모수상작 모음 집』. 성남: 한국국제협력단.

Conor M. Savoy, and Charles F. Rice. 2017. "A Report of the CSIS Project on U.S Leadership in Development: Global Development Monitor 2017.” Washington D.C.: Center for Strategic \& International Studies.

Danida(Danish International Development Agency), Conify and Sustainia. 2017. "Hack the future of Development Aid". Denmark: Ministry of Foreign Affairs of Denmark.

GSMA. 2017. "Blockchain for Development: Emerging Opportunities for Mobile, identity and Aid." London: GSMA Mobile for Development Foundation.

Heather Starkie. 2017. "Usage of Blockchain in UN System : A Desk Review." Geneva: United Nations.

Marina Niforos. 2018. "Blockchain in Financial Services in Emerging Markets Part I: Current Trends.” Washington DC: International Finance Corporation (IFC) of World bank Group.

Kai Schmidt, and Philipp Sandner. 2017. "Solving Challenges in Developing Countries with Blockchain Technology.” Frankfurt: Frankfurtschool Blockchain center.

Nakamoto Satoshi. 2008. "Bitcoin: A peer-to-peer electronic cash system." available at http://bitcoin.org/bitcoin.pdf (접속일: 2018.05.30.)

Kibum Kim, and Taewon Kim. 2017. “2017 OECD Global Anti-Corruption \& Integrity Forum: Does Technology Against Corruption Always Lead to Benefit? Potential Risks and Challenges of the Blockchain Technology." presented at Research Edge Poster sessions of the Global Anti-Corruption \& Integrity Forum on 31-30 March, 2017, France.

Michael Pisa, and Matt Juden. 2017. "Blockchain and Economic Development: Hype vs. Reality.” Washington D.C.: Center for Global Development.

Mckinsey Global Institute. 2016. "Digital Finance for All: Powering Inclusive Growth in Emerging Economies.” New York: Mckinsey \& Company. Nir Kshetri, and Jeffrey Voas. 2018. "Blockchain in Developing Countries.” IT 


\section{Professional Vol.2(2): 11-14.}

Philip Boucher, Susana Nascimento, and Mihalis Kritikos. 2017. "How blockchain change our lives: In depth Analysis.” Brussel: European Parliamentary Research Service, European Union.

World Bank. 2016. "Remittance Prices Worldwide: An Analysis of Trends in Cost of Remittance Services.” Washington D.C: World Bank Group. World Bank. 2017. "Distributed Ledger Technology (DLT) and Blockchain:

Fintech note 1.” Washington D.C: International Bank for Reconstruction and Development of the World Bank Group.

권승원. 2018. “요르단 난민수용소, 블록체인 기반 난민지원시스템 제공.” Tokenpost Koea 홈페이지, 2018년 4월 13일 게재. (https://tokenpost.kr/article-2222) (접 속일: 2018.05.30.).

신버들. 2018. “북한 지원에 블록체인 기술 적용한다면: 원조 물품 받은 北, 주민정보 공유 가능." 중앙일보 이코노미스트 홈페이지, 2018년 1월 20일 게재.

(https://news.joins.com/article/22302472) (접속일: 2018.06.23.).

유성민. 2017. “블록체인으로 개방형 전자정부 완성한다.” 테크M 홈페이지, 2017년 9월 5일 게재. (http://techm.kr/bbs/board.php?bo_table=article\&wr_id=4197) (접 속일: 2018.07.23.).

원재연. 2018. "[신비한 코인사전]<16>금융 소외계층을 위한 결제 플랫폼 '스텔라' ” 서울 경제 홈페이지, 2018년 7월 2일 게재. (http://www.sedaily.com/News/News View/NewsPrint?Nid=1S1XGRU7QP)（접속일 2018.05.30.). 전희수. 2017. “아프리카에서 시작되는 새로운 변화, 모바일 머니.” 「나라경제 칼럼」 2017년 11월호 DDI 정보센터 나라경제 홈페이지 (https://eiec.kdi.re.kr/publish/ nara/column/view.jsp?idx=11305) (접속일: 2018.07.30.).

최문위·최은창. 2017. "Can blockchain technology help poor people around the world? 블록체인기술이 빈곤층을 도울 수 있을까요?” GP3 Korea Poverty Info. Org 홈페이지, 2017년 12월 20일 게재. (https://m.blog.naver.com/gp3project/ 221112176044) (접속일: 2018.07.23.).

하이레. 2018. “유엔 세계식량계획기구(WFP), 이더리움 기반 송금 시스템으로 난민 지 원.” Tokenpost Korea 홈페이지, 2018년 2월 20일 게재. (https://tokenpost.kr/ article-1552) (접속일: 2018.05.31.). 
한국경제 매거진. 2018. "비트코인 여걸이 아프리카로 향한 이유." 한국경제매거진 홈페 이지, 2018년 6월 13일 게재. (http://magazine.hankyung.com/business/apps/ news?popup=0\&nid $=01 \& c 1=1002 \&$ nkey $=2018061101176000211 \&$ mode $=$ sub_ view) (접속일: 2018.07.01.).

한승환. 2017. “블록체인에 대하여: 리플과 스텔라 비교 그리고 한계점." 모비인사이드 홈페이지, 2017년 8월 29일 게재. (http://www.mobiinside.com/kr/2017/08/29/ ripple-stellar-blockchain/) (접속일 2018.07.31.).

The 4th Wave. 2018. “블록체인은 이머징국가에서 효과를 거둘 것이다." the 4th wave 홈페이지, 2018년 1월 29일 게재. (https://www.the4thwave.co.kr/index.php/ 2018/01/29/blc01291/) (접속일: 2018.06.01.).

Ahmad Sufian Bayram. 2018. "Here are three ways blockchain can change refugees' lives." posted on World Economic Forum website on 25 Jun, 2018, available at https://www.weforum.org/agenda/2018/06/three-ways ${ }^{-}$ blockchain-change-refugees-lives (접속일: 2018.06.30.).

Team Ripple. 2018. "Democratizing Global Payments: xRapid's Cost Savings and Benefits." posted on Ripple official Website on Jun 14, 2018, available at https://ripple.com/insights/democratizing-global-payments-xrapids-cost -savings-benefits/ (접속일: 2018.06.15.).

Bitpesa 공식 홈페이지: https://public.bitpesa.co (접속일: 2018.07.10.).

Ripple 공식 홈페이지: https://ripple.com (접속일: 2018.07.02.). 